\title{
THE BEAUTY OF GARNETS IS ETERNA
}

\author{
M I T J A G U ŠT I N
}

\begin{abstract}
This paper addresses several small belt buckles made of gold or copper-alloy with garnets or almandines inlays, as typical migration-period jewellery products of the Hunnic and Gothic cultural circles. Despite appearing on the antiquities market without any information on the finding context, they still deserved to be published on account of some peculiarities and so-far unknown variations of the motifs and details, whose examination will improve our knowledge of the jewellery production of the migration period.
\end{abstract}

Keywords: Migration Period, small buckles, polychrome style.

When participating in a Festschrifts to a person who we either hold dear or admire as a model in research and scholarly endeavours, the character of such paper can be twofold. We can either produce a paper praising the jubilee's personality and his or her opus, or we can write a contribution towards a theme from the sphere of his or her scholarly interests. I am glad to use this opportunity to acquaint Karol Pieta and the academic community with several interesting belt buckles from the treasury of the European heritage of the migration period.

\section{A CONTRIBUTION TO THE TREASURY OF POLYCHROME STYLE}

Almandine, a silicate mineral from the garnet group, was among the most popular decorative precious stones in Late Antiquity, used in the manufacturing of polychrome-style jewellery in Pontus, the Mediterranean, and later even by Germanic jewellers. The name almandine (carbunculus alabandicus in Pliny the Elder) derives from the province of Alabanda in Caria in south-western Asia Minor, where garnets, including almandines, were used in ancient jewellery manufacturing. The almandine stands out in the whole garnet group for its red colour. In antiquity it was mostly inserted in gold jewellery, while from the $3^{\text {rd }}$ and $4^{\text {th }}$ c. it was executed in the cloisonné technique, featuring small, polished stone tiles set into special compartments ('beds'). ${ }^{1}$ A peculiarity of the crystal garnet (lat. granatus $=$ corn) lies in the fact that some of them have the same shape and colour as pomegranate seeds (Punica granatum), and are as such often inlaid in the jewellery without cutting (Pavlovič 2017, 72).

The word polychrome denotes well-defined decoration distinguished by a glittering effect in a variety of colours, but also in one colour combined with a gold ground and semi-precious stones, glass, or enamel. This style, mostly employed by late antique eastern Mediterranean and Black Sea workshops in Pontus, Syria and Palmyra, and especially in Crimean Kerch in the late $4^{\text {th }}$ c., was designed for the barbarian elites, above all the Huns, Sarmatians, and Germanic tribes, who were keen on polychrome-decorated weapons, horse harness, and jewellery. At the beginning of the $5^{\text {th }} \mathrm{c}$., valuable examples of this style spread massively in the hinterland of the northern Black Sea, and from the Middle Danube area to the western fringes of the Pannonian Plain, as transpires from a number of elite graves of the so-called Untersiebenbrunn horizon. A small number of such finds stem from the area stretching from western Europe to the Atlantic coast (Kazanski 1996). The popularity of the polychrome style among the Huns had an effect on the elites of the neighbouring Alani and Sarmatians. In the aftermath of the fall of the Hunnic Empire in 454, the former Hunnic vassals Ostrogoths disseminated the polychrome style along the Apennines, while the Visigoths brought it to the Pyrenean Peninsula (Vinski 1986, 21).

Typical for the Italian Peninsula is the manufacturing of jewellery in various stylistic combinations (polychrome, granulation, enamel, and so on), in accordance with local late antique tradition but also

\footnotetext{
1 Although in Classical Antiquity garnets were not employed on a large scale, they were mostly used as the inlays in gems and medallions in the manufacturing of prestigious jewellery (Pion et al. 2020, 835, 850).
} 

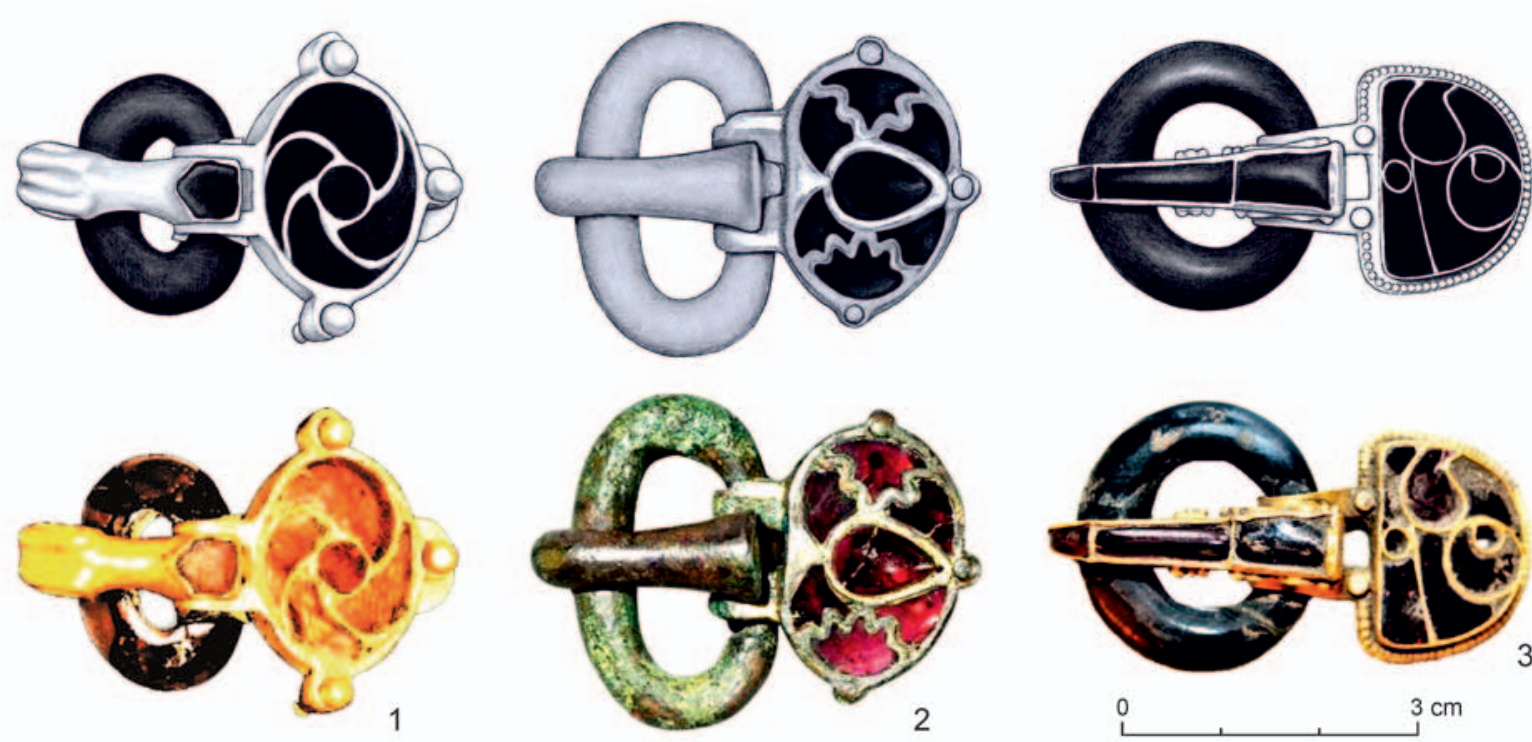

Fig. 1. Polychrome buckles from the antiquities market of the migration period archaeological treasuries. 1, 2- without scale (the photographs-based drawings were made by Janže Lorber, Krška vas).

with tastes of the Ostrogothic rulers. As the successors to the Ostrogothic Empire, the Longobards adopted and transformed the polychrome style of decoration, transmitting it as such to the Merovingian cultural circles of the Bajuwars Alamanni, and Franks. From there, the polychrome style was conveyed to western European regions, where it flourished in all its splendour to the mid- $7^{\text {th }} \mathrm{c}$. (Pion et al. 2020, 835). One of the testimonies for this is an incredibly rich find of the warrior-equipment depot from Staffordshire (West Midlands, UK; Fern/ Dickinson/Webster 2019).

Late antique and early medieval polychromes are represented by two specific styles of jewellery decoration, weapons, and horse harness. The first group comprises artefacts with the visible gold ground and spaced cells, each taking a convex- or flat-polished almandine, garnet or glass inlay (see e.g. Zmajevac). The other group is characterised by the surface covered in a network of variously shaped cells ('beds') that, as a rule, hold smoothly polished tiny tiles made of larger almandines or some other material; this is called cloisonné (cf. e.g. Potoci-Vrba; Vinski 1986, 22).

I would like to use this opportunity to shortly bring attention to two small gold buckles and one copper-alloy, all three decorated in polychrome (Fig. 1). Their photographs have appeared on the antiquities market, while the artefacts probably finished in private collections.
In many cases the appearance of gold artefacts on the antiquities market rightly provokes suspicion about their authenticity. In this example, however, I believe that the photograph gives a reliable proof that the buckles are originals, despite the lack of any information on the finding circumstances. Therefore, these objects deserve to be published, and the arguments for this should be the same as I adduced when publishing a group of peculiar finds from the antiquities market, allegedly found in the surrounding of Brza Palanka in Serbia, in the territory of Roman Egeta. Those objects were made in the shape of a bird of prey, fish, and cicada, respectively, and were decorated with garnets or almandines (Guštin 2020, 127-130, fig. 4).

Small gold buckles decorated in the polychrome style are often found as outstanding migrationperiod grave goods. In their basic conception, the two gold and one copper-alloy examples under discussion here correspond with many other small buckles that normally possess a belt-plate covered in four or five geometrically arranged cells carrying almandines; three fixing rivets are spaced regularly along the belt-plate's rim. An elongated smooth prong reaches over a massive gold or copper-alloy oval loop (e.g. Bona 1991). Our two examples stand apart from the general type especially on account of the loop made of rock crystal (Fig. 1: 1$)^{2}$ or other semi-precious stone, possibly porphyry (Fig. 1: 2$)^{3}$.

\footnotetext{
2 E.g. Kranj-Lajh, lacking the grave context (Stare 1980, 83, pl. 134: 7; Knific/Nabergoj 2016, 55, fig. 64).

3 E.g. Kranj-Lajh, grave 12/2004 (Šmit et al. 2014).
} 
The differences are displayed in the arrangement of the cells with garnets or almandines on the prong and in details of the shapes of the cells on the beltplate, which are not regularly geometric. The buckle in Fig. 1: 3 is specific for its belt-plate whose rim is decorated with a beading motif.

According to the ellipsoidal and semi-circular shape, the belt-plates of small buckles are classified as type A (after Kazanski), which spread from the western coast of the Iberian Peninsula (Beja) to the Ural Mountains (Kosasar, Novogregorievka), with the concentration in the territory of the former Roman province of Pannonia and to a lesser extent the wider hinterland of the Black Sea (Kazanski 1996, 121-123, map in fig. 9; cf. Eger 2015, fig. 15). The buckle in Fig. 1: 2 is relatively common for its shape, a smooth prong and undulating cells' contours, while the buckles in Fig. 1: 2 and 1: 3 stand out for their craftsmanship and particular shapes of the prongs decorated with inlaid stones, with one of them specific for its widened and moulded tip (Fig. 1: 1). The belt-plate cells of the buckle in Fig. 1: 3 , executed in a kind of Jugendstil/Art Nouveau manner, place this artefact on top of the artistic achievements of a period that in itself stands out in decorative richness.

\section{Description of the buckles based on the photographs}

- Fig. 1: 1. Gold buckle of unknown size, with the loop made of rock crystal. A small ellipsoidal belt-plate is decorated with five cells, with the central one round and the remainder spirally shaped. Judging from the photograph, the cells held flat-polished garnets or almandines. Three rivets fixed the plate to the belt. At the beginning of the prong there is a largish cell holding a flat garnet or almandine. The shape of the wide moulded tip of the prong stands apart from the rule.

- Fig. 1: 2. Copper-alloy buckle of unknown size, with the loop made of copper-alloy. A small ellipsoidal beltplate is decorated with seven cells, with the central one tear-shaped and the remainder deriving the appearance from their undulating contours. The side cells bear flatpolished garnets or almandines, while the central stone is convex-polished. The surface of the belt-plate shows traces of gilding. Three rivets fixed the plate to the belt.

- Fig. 1: 3. Gold buckle ca. $4.5 \mathrm{~cm}$ long, with the loop made of rock crystal of almandine colour. A small semi-circular belt-plate is rimmed with the motif of ribbed wire. The belt-plate carries eight differently shaped cells with flatpolished garnets or almandines, while at the beginning of the buckle bar there are two rivets for fixing on the belt. An elongated prong is decorated with three cells bearing convex-polished garnets or almandines, while its sides are embellished with granulation and a thin wire.

\section{BIBLIOGRAPHY}

Bóna 1991 - I. Bóna: Das Hunnenreich. Budapest - Stuttgart 1991.

Eger 2015 - Ch. Eger: Zur Deutung reich ausgestatteter Männergräber des mittleren 5. Jhs. im Mittelmeerraum. In: T. Vida (ed.): Romania Gothica II. The Frontier World Romans, Barbarians and Military Culture. Proceedings of the International Conference at the Eötvös Loránd University. Budapest, 1-2 October 2010. Budapest 2015, 237-283.

Fern/Dickinson/Webster 2019 - C. Fern/T. Dickinson/L. Webster (eds.): The Staffordshire Hoard: An Anglo-Saxon Treasure. Research Report of the Society of Antiquaries of London 80. London 2019.

Guštin 2020 - M. Guštin: Profesor Zdenko Vinski u Ljubljani - nekoliko primjera polikromnog stila nepoznatog porijekla. In: M. Jarak/M. Bunčić (ur.): Zdenko Vinski, život $i$ znanstveni rad. Zbornik radova sa znanstvenog skupa održanog u Zagrebu 2016. godine. Zagreb 2020, 147-159.

Kazanski 1996 - M. Kazanski: Les tombes "princières" de l'horizon Untersiebenbrunn, le problème del'identification ethnique. In: L'identité des populations archéologiques. Actes des XVI rencontres internationales d'archéologie et d'histoire d'Antibes. Sophia Antipolis 1996, 109-126.

Knific/Nabergoj 2016 - T. Knific/T. Nabergoj: Srednjeveške zgodbe s stičišča svetov. Ljubljana 2016.

Pavlovič 2017 - D. Pavlovič: Dragocenosti iz daljne Indije. In: G. Oitzl (ur.): Preteklost pod mikroskopom. Naravoslovne raziskave v muzeju. Ljubljana 2017, 71-76.

Pion et al. 2020 - C. Pion/B. Gratuze/P. Périn/T. Calligaro: Bead and Garnet Trade between the Merovingian, and Indian Worlds. In: B. Effros/I. Moreira (eds.): The Oxford Handbook of the Merovingian World. New York 2020, 819-859.

Šmit et al. 2014 - Ž. Šmit/H. Fajfar/M. Jeršek/T. Knific/J. Lux: Analysis of garnets from the archaeological sites in Slovenia. Nuclear Instruments and Methods in Physics Research B 328, 2014, 89-94.

Stare 1980 - V. Stare: Kranj, nekropola iz časa preseljevanja ljudstev. Katalogi in monografije 18. Ljubljana 1980.

Vinski 1986 - Z. Vinski: Epoha seobe naroda. In: N. Tanasijević-Popović (ed.): Umjetnost na tlu Jugoslavije. Rani srednji vijek. Beograd - Zagreb - Mostar 1986, 19-27.

Prof. Phd., Phd. h. c. Mitja Guštin

emeritus of University of Primorska

Pusterla 7

SI - 6330 Piran

mitja.gustin@upr.si 
